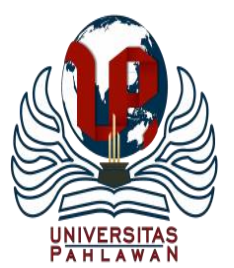

Edukatif : Jurnal Ilmu Pendidikan Volume 2 Nomor 3 Tahun 2020 Halm 232 - 243

EDUKATIF: JURNAL ILMU PENDIDIKAN

Research \& Learning in Education

https://edukatif.org/index.php/edukatif/index

\title{
Pengaruh Pembelajaran Daring terhadap Minat Belajar Siswa pada Masa COVID-19
}

\author{
Ria Yunitasari ${ }^{1}$, Umi Hanifah ${ }^{2}$ \\ Fakultas Tarbiyah dan Keguruan UIN Sunan Ampel ${ }^{1,2}$ \\ E-mail : riayunitasarinita@gmail.com ${ }^{1} \underline{\text { umihanifah@ } \underline{\text { uinsby.ac.id }}{ }^{2}}$
}

\begin{abstract}
Abstrak
Penelitian ini menggunakan penelitian kualitatif. Penelitian kualitatif ini bersifat deskriptif menggunakan analisis data kualitatif sehingga menjadi paparan data yang mudah dipahami. Pembelajaran pada sekolah dasar atau Madrasah Ibtidiyah (MI) dalam penelitian ini menggunakan pembelajaran daring atau biasa disebut dengan pembelajaran jarak jauh (dari rumah) dengan bimbingan orang tua dan guru di sekolah. Siswa melakukan pembelajaran daring dan berinteraksi dengan guru menggunakan beberapa aplikasi yang dipakai seperti Google Classroom, Zoom, Google Meet dan Whatsapp Group. Penelitian ini bertujuan untuk mengetahui pengaruh pembelajaran daring terhadap minat belajar siswa pada masa COVID-19. Responden yang diambil adalah siswa, guru dan orangtua siswa di wilayah Desa Karanggayam Sidoarjo. Hasil penelitian menunjukkan bahwa pembelajaran daring pada masa pandemi COVID-19 sangat berpengaruh terhadap minat belajar siswa, siswa merasa bosan karena tidak bertemu dengan teman dan gurunya secara langsung.
\end{abstract}

Kata kunci: pembelajaran daring, minat belajar, COVID-19

\begin{abstract}
This research uses qualitative research. This qualitative research is descriptive using data analysis so that it becomes easy to understand data exposure. Learning in primary schools or madrasas ibtidiyah (mi) in this study uses online learning or commonly referred to as distance learning (from home) with the guidance of parents and teachers at school. Students do online learning and interact with the teacher using several applications in use such as google classroom, zoom, google meet and whatsapp group. This study aims to determine the effect of online learning on student interest in co-19. The respondents taken were students, teachers and parents of students in the Karanggayam village area, Sidoarjo. The results showed that online learning during the Covid-19 pandemic was very influential on students' interest in learning, students felt bored because they did not meet with their friends and teachers directly.
\end{abstract}

Keywords: online learning, interest to learn, COVID-19

Copyright (c) 2020 Ria Yunitasari, Umi Hanifah

$\triangle$ Corresponding author

Address : Karanggayam, Sidoarjo, Jawa Timur

Email : riayunitasarinita@gmail.com

ISSN 2656-8071 (Media Cetak)

Phone : 0895366983318

ISSN 2656-8063 (Media Online)

DOI: https://doi.org/10.31004/edukatif.v2i3.142 
233 Pengaruh Pembelajaran Daring terhadap Minat Belajar Siswa pada Masa COVID-19 - Ria Yunitasari, Umi Hanifah

DOI: https://doi.org/10.31004/edukatif.v2i3.142

\section{PENDAHULUAN}

Virus corona atau COVID-19 pertama kali muncul atau ditemukan di kota Wuhan, China pada akhir 2019 lalu. Virus ini belum juga ditemukan penawarnya hingga kini tidak terkendali. Sudah lebih dari 200 negara yang ada di dunia melaporkan adanya kasus virus corona (Yunita, 2020). Pandemi COVID-19 merupakan musibah yang memilukan bagi seluruh penduduk bumi. Seluruh kehidupan manusia di bumi terganggu, tanpa kecuali pendidikan. Banyak negara memutuskan menutup sekolah, perguruan tinggi maupun universitas, termasuk negara Indonesia (Syah, 2020). Coronavirus atau virus corona adalah keluarga besar virus yang menyebabkan infeksi saluran pernapasan atas ringan hingga sedang, seperti penyakit flu. Ada banyak orang terinfeksi virus ini, setidaknya satu kali dalam hidupnya (Fadli, 2020).

Penyebaran virus corona ini pada awalnya sangat berdampak bagi dunia ekonomi yang mulai lesu, dan akhirnya kini berdampak juga dirasakan oleh dunia pendidikan. Kebijakan yang sudah diambil oleh banyak negara dan termasuk Indonesia juga dengan meliburkan seluruh aktivitas pendidikan, dan membuat pemerintah dan lembaga terkait harus menghadirkan alternatif untuk proses pendidikan bagi peserta didik maupun mahasiswa yang sekarang tidak bisa melaksanakan proses pembelajaran atau proses pendidikan pada suatu lembaga pendidikan (Dewi, 2020).

Adanya virus COVID-19 pada tahun 2020 memberikan dampak yang luar biasa hampir pada semua bidang, salah satunya pada bidang pendidikan. Dengan adanya virus COVID-19 ini membuat proses pembelajaran menjadi berubah dari yang tatap muka menjadi pembelajaran jarak jauh, tetapi dalam keadaan seperti ini guru masih tetap harus melaksanakan kewajibannya sebagai pengajar, dimana guru harus memastikan siswa dapat memperoleh informasi/ilmu pengetahuan untuk diberikan kepada siswa (Aulia, 2020).

Di Indonesia, pembelajaran jarak jauh atau daring ini dimulai pada tanggal 16 maret 2020, dimana anak mulai belajar dari rumahnya masingmasing tanpa perlu pergi ke sekolah. Berbicara mengenai pembelajaran jarak jauh atau daring maka pentingnya penguasaan ilmu teknologi bagi seorang guru agar pembelajaran jarak jauh tetap berjalan dengan efektif disaat pandemi seperti ini.

Konsekuensi dari penutupan Lembaga Pendidikan secara fisik dan mengganti dengan belajar di/dari rumah sebagaimana kebijakan pemerintah adalah adanya perubahan sistem belajar mengajar. Pengelola sekolah, siswa, orangtua, dan tentu saja guru harus bermigrasi ke sistem pembelajaran digital atau online, yang lebih dikenal dengan istilah e-learning atau dikenal dengan istilah pembelajaran dalam jaringan atau "pembelajaran daring" di Indonesia. Negara Indonesia juga relatif tidak berbeda dengan negara lain. Meskipun menyadari bahwa ada disparitas terhadap akses teknologi pembelajaran dan beragamnya latar belakang orang tua, Kementerian Pendidikan dan Kebudayaan Republik Indonesia dengan tegas memberlakukan kebijakan pembelajaran daring (Wahyono \& Husamah, 2020). 
234 Pengaruh Pembelajaran Daring terhadap Minat Belajar Siswa pada Masa COVID-19 - Ria Yunitasari, Umi Hanifah

DOI: https://doi.org/10.31004/edukatif.v2i3.142

Kelangsungan pendidikan selama pandemi akan tergantung pada berbagai faktor, seperti tingkat persiapan sekolah, kesiapan orang tua/keluarga, serta kesiapan guru. Pertimbangan harus diberikan pada kebutuhan semua siswa untuk terus memberikan pendidikan selama berlangsungnya pandemi. Selain menggunakan hardcopy dari bahan ajar, seperti buku, buku kerja, dan dokumen lain yang dikirim melalui pos atau kurir, sekolah dapat menggunakan berbagai solusi berbasis teknologi untuk meningkatkan kemungkinan siswa dapat melanjutkan aktivitas pembelajaran mereka.

Wabah Corona Virus Disease (COVID-19) yang melanda lebih dari 200 negara di dunia, telah memberikan tantangan tersendiri bagi lembaga pendidikan. Mengantisipasi penularan virus tersebut pemerintah telah mengeluarkan berbagai kebijakan, seperti isolasi, social and physical distancing hingga pembatasan sosial berskala besar (PSBB). Kondisi ini mengharuskan warganya untuk tetap stay at home, bekerja, beribadah dan belajar di rumah. Disisi lain demi tetap menjaga dunia pendidikan bisa tetap berjalan dengan baik serta mendukung pemerintah dalam mendukung psysical distanting ditengah Pendemi COVID 19 sesuai intruksi presiden untuk tetap dirumah, belajar dirumah, bekerja dirumah, ibadah dirumah (Pakpahan \& Fitriani, 2020).

Di Indonesia, sudah memberlakukan kebijakan Pembatasan Sosial Berskala Besar atau biasa disebut PSBB untuk lebih menekan penyebaran virus ini di Indonesia. Kegiatan yang ada diluar rumah selama kebijakan ini masih diterapkan maka harus dihentikan terlebih dahulu sampai pandemi ini sudah mereda (Harnani, 2020).

Pembelajaran daring dapat dijadikan solusi pembelajaran jarak jauh ketika terjadi bencana alam. Seperti yang terjadi saat ini ketika pemerintah menetapkan kebijakan social distancing. Social distancing diterapkan oleh pemerintah dalam rangka membatasi interaksi manusia dan menghindarkan masyarakat dari kerumunan agar terhindar dari penyebaran virus COVID-19 (Syarifudin, 2020,p.31).

Kebijakan ini menjadikan kegiatan belajar mengajar dalam konteks tatap muka yang biasa dilakukan di sekolah dihentikan sementara. Pemerintah mengganti pembelajaran dengan sistem pembelajaran daring melalui aplikasi pembelajaran daring yang sudah ada. Dengan adanya kebijakan ini menjadikan pembelajaran daring yang sebelumnya masih tidak maksimal diterapkan menjadi satu-satunya pilihan bentuk pembelajaran.

Pembelajaran harus tetap berlangsung, walaupun terjadi bencana pandemi global yang menjadikan pemerintah menerapkan social distancing pada dunia pendidikan. Solusi paling tepat dengan pandemi ini adalah pembelajaran daring. Pembelajaran daring pada dasarnya merupakan pembelajaran yang dilakukan secara virtual memalui aplikasi virtual yang tersedia. Walaupun demikian, pembelajaran daring harus tetap memperhatikan kompetensi yang akan diajarkan.

Pembelajaran daring bukan sekedar materi yang dipindah melalui media internet, bukan juga sekedar tugas dan soal-soal yang dikirimkan 
235 Pengaruh Pembelajaran Daring terhadap Minat Belajar Siswa pada Masa COVID-19 - Ria Yunitasari, Umi Hanifah

DOI: https://doi.org/10.31004/edukatif.v2i3.142

melalui aplikasi sosial media. Pembelajaran daring harus direncanakan, dilaksanakan, serta dievaluasi sama halnya dengan pembelajaran yang terjadi di kelas.

Pembelajaran ini yang dilaksanakan pada Sekolah Dasar atau Madrasah Ibtidiyah (MI) juga menggunakan pembelajaran dari atau biasa disebut dengan pembelajaran jarak jauh dengan bimbingan orangtua yang biasanya dengan bimbingan guru di sekolah (Dewi, 2020,p.56). Siswa melakukan pembelajaran daring dan berinteraksi dengan guru menggunakan beberapa aplikasi yang di pakai seperti Google Classroom, Zoom, Google Meet, Whatsapp Group dan lain sebagainya.

Seluruh jenjang pendidikan dari Sekolah Dasar/Ibtidaiyah sampai Perguruan Tinggi (Universitas) baik yang berada di bawah Kementerian Pendidikan dan Kebudayaan RI maupun yang berada di bawah Kementerian Agama RI semuanya memperoleh dampak negatif karena pelajar, siswa dan mahasiswa "dipaksa" belajar dari rumah karena pembelajaran tatap muka ditiadakan untuk mencegah penularan COVID-19. Padahal tidak semua pelajar, siswa dan mahasiswa terbiasa belajar melalui online. Apalagi guru dan dosen masih banyak belum mahir mengajar dengan menggunakan teknologi internet atau media sosial terutama di berbagai daerah (Purwanto et al., 2020).

Pembelajaran online juga sangat mempermudah pelajar dalam mengikuti pembelajaran daring, seperti yang sudah diterapkan sekarang ini ketika banyak sekolah yang diliburkan karena untuk mencegah penyebaran COVID-19 dan sudah digantikan dengan pembelajaran yang diterapkan dirumah dengan menggunakan pembelajaran daring (online).

Pembelajaran daring bukan hanya berkutat dengan internet, melainkan ada aspek yang lebih penting yaitu "lebih aman (safer)". Yang biasanya kita kenal Learning Management Systems (LMS) sekarang yang sering digunakan untuk proses pembelajaran daring sebagai komponen penting $e$ learning (Sobron et al., 2019,p.30). Peserta didik lebih nyaman dengan menggunakan LMS dalam berinteraksi dengan tutor atau guruya.

Pembelajaran daring mempuyai banyak manfaat, yang pertama dapat membangun komunikasi dan diskusi yang sangat efisien antara guru dengan murid, kedua siswa saling berinteraksi dan berdiskusi antara siswa yang satu dengan yang lainnya tanpa melalui guru, ketiga dapat memudahkan interaksi antara siswa guru, dengan orang tua, keempat sarana yang tepat untuk ujian maupun kuis, kelima guru dapat dengan mudah memberikan materi kepada siswa berupa gambar dan vidio selain itu murid juga dapat mengunduh bahan ajar tersebut, keenam dapat memudahkan guru membuat soal dimana saja dan kapan saja (Meidawati \& Veteran Bangun Nusantara Sukoharjo, 2019).

Sistem pembelajaran yang dilaksanakan melalui komputer atau laptop yang terhubung dengan koneksi jaringan internet. Guru juga dapat melakukan pembelajaran bersama diwaktu yang sama menggunakan grup di media sosial seperti media Whatsapp (WA), Telegram, Instagram, aplikasi Zoom ataupun media lainnya sebagai media pembelajaran. Dengan itu guru dapat 
236 Pengaruh Pembelajaran Daring terhadap Minat Belajar Siswa pada Masa COVID-19 - Ria Yunitasari, Umi Hanifah

DOI: https://doi.org/10.31004/edukatif.v2i3.142

memastikan siswa mengikuti pembelajaran dalam waktu yang bersamaan, meskipun di tempat yang berbeda.

Model pembelajaran daring adalah model atau pola pembelajaran pilihan guru untuk merencanakan proses belajar yang sesuai dan efisien guna mencapai tujuan pembelajaran dengan memanfaatkan jaringan komputer dan internet (Yanti et al., 2020,p.56). Model pembelajaran ini juga perlu dirancang dengan baik agar pengalaman belajar peserta didik itu berkesan dan juga dapat mencapai tujuan pembelajaran.

Minat belajar adalah salah satu faktor yang sangat penting untuk keberhasilan belajar yang dimiliki siswa, minat muncul dari dalam diri siswa itu sendiri. Faktor dari luar minat belajar yaitu bagaimana cara guru tersebut mengajar. Peran guru sangat penting untuk menumbuhkan minat belajar siswa salah satu dengan cara mengajar yang menyenangkan, memberikan motivasi yang membangun (Riamin, 2016).

Minat belajar adalah suatu rasa untuk menyukai atau juga tertarik pada suatu hal dan aktivitas belajar tanpa ada yang menyuruh untuk belajar (Ricardo \& Meilani, 2017). Minat belajar juga merupakan faktor pendorong untuk siswa dalam belajar yang didasari atas ketertarikan atau juga rasa senang keinginan iswa itu untuk belajar.

Minat belajar merupakan sikap ketaatan dalam kegiatan proses belajar, baik yang menyangkut perencanaan jadwal belajar yang dimilikinya maupun inisiatif dirinya sendiri melakukan usaha tersebut dengan bersungguhsungguh dalam belajar (Andriani \& Rasto, 2019).
Minat belajar juga mempunyai indikatorindikator di dalamnya yaitu adanya perasaan tertarik dan juga senang untuk belajar, adanya pasrtisipasi yang aktif, adanya kecenderungan untuk memperhatikan dan daya konsentrasi yang besar, memiliki perasaan positif dan kemauan belajar yang terus meningkat, adanya kenyamanan pada saat belajar, dan dimilikinya kapasitas dalam membuat keputusan berkaitan dengan proses belajar yang dijalaninya.

Setelah melakukan kajian literasi jurnaljurnal, sehingga bisa diadakannya penelitian mengenai bagaimana pengaruh pembelajaran daring terhadap minat belajar siswa SD / MI pada masa COVID-19 untuk menjawab bagaimana pengaruh pembelajaran daring terhadap minat belajar siswa tersebut dari sudut pandang guru, siswa dan orangtua siswa yang ada di daerah desa Karanggayam Sidoarjo. Karena dengan keadaan yang baru ini, pelaksanaan pembelajaran tidak akan sama dengan pembelajaran yang biasanya dilakukan di sekolah.

Penelitian ini fokus pada pengaruh pembelajaran daring terhadap minat belajar siswa dalam hal berpengaruhkan pembelajaran tersebut dengan minat belajar siswa yang dilakukan oleh pihak sekolah. Penelitian ini bertujuan untuk mengetahui pengaruh pembelajaran daring terhadap minat belajar siswa pada masa COVID19 saat ini terjadi.

\section{METODE PENELITIAN}

Bentuk penelitian yang digunakan dalam penelitian ini yaitu metode penelitian kualitatif. Penelitian kualitatif merupakan penelitian yang 
237 Pengaruh Pembelajaran Daring terhadap Minat Belajar Siswa pada Masa COVID-19 - Ria Yunitasari, Umi Hanifah

DOI: https://doi.org/10.31004/edukatif.v2i3.142

bersifat deskriptif dan cenderung menggunakan analisis. Karakteristik penelitian kualitatif yaitu melakukan penelitian dalam kondisi yang alamiah, langsung ke sumber data, peneliti menjadi instrumen kunci, menyajikan data-data dalam bentuk kata-kata atau gambar dan tidak menekankan angka-angka, melakukan analisis data. Metode penelitian kualitatif ini tidak dimanipulasi oleh peneliti, analisis data berdasarkan fakta-fakta yang ditemukan di lapangan (Sugiyono, 2015).

Sumber data yang diambil oleh peneliti yaitu hasil wawancara peneliti dengan orang tua siswa dan guru yang ada disekitar desa Karanggayam Sidoarjo. Data yang diperoleh dari orang tua siswa ini berupa opini secara individual yang berdasarkan jawaban dari hasil wawancara dengan peneliti. Setelah itu data akan dikumpulkan sesuai dengan apa yang diinginkan oleh peneliti. Selain sumber data hasil wawancara dari orang tua siswa dan guru yang disekitar rumah peneliti, bisa juga hasil dokumentasi berbagai literatur yaitu berupa buku, jurnal, artikel ataupun yang berkaitan dengan penelitian.

Subjek penelitian ini adalah siswa SD/MI yang mengikuti pembelajaran selama masa pandemi COVID-19 ini, guru dan orang tua siswa. Mendapatkan total 13 responden, 3 orang guru yang ada di Desa Karanggayam Sidoarjo, 2 orang tua yang ada disekitar rumah tidak semua orang tua yang mau diwawancarai jadi hanya 2 orang saja yang bisa diwawancarai, 8 orang siswa SD/MI disekitar rumah. Pengumpulan data yang dilakukan melalui Google Form.
Untuk memerika keabsahan dalam penelitian, peneliti menggunakan teknik referensi yang diperoleh selama penelitian seperti jurnal penelitian, jawaban responden. Untuk menguji dan mengoreksi hasil penelitian yang sudah dilakukan.

\section{HASIL DAN PEMBAHASAN PENELITIAN}

Pandemi COVID-19 merupakan musibah yang memilukan bagi seluruh penduduk bumi. Seluruh kehidupan manusia di bumi terganggu, tanpa kecuali pendidikan. Banyak negara memutuskan menutup sekolah, perguruan tinggi maupun universitas, termasuk negara Indonesia. Coronavirus atau virus corona merupakan keluarga besar virus yang menyebabkan infeksi saluran pernapasan atas ringan hingga sedang, seperti penyakit flu. Banyak orang terinfeksi virus ini, setidaknya satu kali dalam hidupnya (Fadli, 2020).

Pada masa pandemi COVID-19 ini siswa belajar di sekolah dialihkan dengan belajar dari rumah. Meskipun belajar dari rumah siswa tetap berlajar seperti di sekolah. Cuma media yang digunakan menggunakan via Zoom, Google Meet atau teleconference lainnya. Pada saat pembelajaran dari rumah siswa juga diberikan materi seperti belajar di sekolah yang berbeda hanya jam belajarnya saja untuk yang lainnya masih sama.

Pembelajaran daring dapat dijadikan solusi pembelajaran jarak jauh ketika terjadi bencana alam. Seperti yang terjadi saat ini ketika pemerintah menetapkan kebijakan social distancing. Social distancing diterapkan oleh pemerintah dalam rangka membatasi interaksi manusia dan menghindarkan masyarakat dari 
238 Pengaruh Pembelajaran Daring terhadap Minat Belajar Siswa pada Masa COVID-19 - Ria Yunitasari, Umi Hanifah

DOI: https://doi.org/10.31004/edukatif.v2i3.142

kerumunan agar terhindar dari penyebaran virus COVID-19 (Syarifudin, 2020,p.31).

Pemerintah menganjurkan seluruh siswasiswa untuk belajar di rumah di bawah pengawasan orang tua. Pertama, anak tetap belajar, dengan menggunakan metode yang dibuat sementara pembelajaran. Pengembangan program pembiasaan perilaku baik di rumah dan orang tua wajib melaporkan tugas yang diberikan setiap harinya dengan video atau foto (Contesa, 2020).

Untuk menggunakan media pada saat pembelajaran daring ini tergantung pihak sekolah untung menggunakan media apa, ada beberapa sekolah yang menggunakan media Zoom untuk melakukan pembelajaran daring bersama siswanya. Ada juga yang menggunakan media Google Meet untuk melakukan pembelajaran daring bersama siswa. Untuk media Google Form biasanya digunakan sebagai alat untuk mengerjakan tugas dan mengumpulkan tugas.

Meskipun belajarnya dengan pembelajaran daring tetapi siswa juga tetap semangat tidak mengeluh dan juga tidak bosan, tetapi ada kalanya siswa bosan dengan pembelajaran ini tapi harus diikuti oleh siswa karena jika tidak mengikuti pembelajaran daring dianggap tidak masuk sekolah. Dari 8 siswa yang mengisi form, ada 5 siswa atau $62,5 \%$ yang merasakan kebosanan mengikuti pembelajaran daring. Untuk 3 orang atau $37,5 \%$ lainnya masih dalam keadaan yang santai atau tidak mengalami kebosanan pada saat mengikuti pembelajaran daring.

Pembelajaran daring tidak berbeda dengan pembelajaran seperti di sekolah, tugas juga masih ada mungkin tidak seperti pada waktu belajar di sekolah hanya saja dikurangi sedikit beban tugasnya. Siswa juga tetap mengerjakan tugas yang diberikan gurunya untuk dikerjakan sebagai pengambilan nilai setiap hari tetapi tugas yang diberikan pun juga tidak setiap hari. Dilihat juga dari kondisi dan situasi pada saat itu jika memungkinkan untuk diberikan tugas bisa diberikan tugas yang sesuai dengan materi jika tidak memungkinkan maka tidak diberikan tugas. Siswa juga harus memperhatikan guru pada saat memberikan materi kepada siswa, agar siswa mengetahui materi apa yang akan diterima pada waktu pembelajaran tersebut. Atau bisa juga dicatat agar tidak lupa.

Pembelajaran daring yang diterapkan lebih cenderung pada bentuk penugasan via aplikasi. Siswa diberikan tugas-tugas untuk diselesaikan kemudian dikoreksi oleh guru sebagai bentuk penilaian dan diberikan komentar sebagai bentuk evaluasi (Syarifudin, 2020).

Pada saat proses pembelajaran daring ini siswa didampingi oleh orang tua dan dibantu oleh orang tua. Ada juga yang tidak di dampingi oleh orang tua dikarenakan bekerja atau kesibukkan lainnya dan siswa tetap melakukan proses pembelajaran daring sendiri. Ketika mendapatkan kesulitan dari materi yang diberikan oleh guru, jika tidak didampingi oleh orang tua, siswa bisa melakukan browsing materi yang didapat untuk membantunya pada saat proses pembelajaran jika itu diijinkan oleh gurunya.

Pembelajaran daring yaitu pembelajaran jarak jauh atau juga bisa disebut belajar daring rumah yang dilakukan secara online oleh guru dan siswa untuk melakukan pembelajaran yang seperti 
239 Pengaruh Pembelajaran Daring terhadap Minat Belajar Siswa pada Masa COVID-19 - Ria Yunitasari, Umi Hanifah

DOI: https://doi.org/10.31004/edukatif.v2i3.142

di kelas. Pembelajaran ini kurang efektif karena masih ada beberapa siswa/orang tua siswa tidak memiliki ponsel dan kendala sinyal internet.

Dalam pembelajaran jarak jauh atau pembelajaran daring sampai saat ini, hanya efektif dalam mengerjakan penugasan yang diberikan oleh gurunya. Tapi, dalam hal pembelajaran untuk memahami konsep sampai refleksi tidak berjalan dengan baik (Ashari, 2020). Perubahan pola belajar dan mengajar tentu tak akan pernah terlepas dari peran guru, terlebih berubah ke pola pembelajaran daring.

Durasi waktu yang diberikan guru kepada siswa ini selama melakukan pembelajaran daring ini cukup berbeda-beda. Ada yang durasi waktunya 3 jam dengan jeda untuk istirahat 30 menit, ada yang kondisional sesuai dengan kondisi siswa dan juga tidak memberatkan siswa, dan ada juga yang 2 jam diberikan waktu istirahat juga selama 30 menit.

Guru memberikan materi pada saat pembelajaran daring menggunakan video animasi yang sesuai dengan materi yang diberikan oleh guru dan juga berupa Power Point (PPT) berisikan materi yang sesuai dengan pembelajaran daring berlangsung. Selama pembelajaran daring guru tidak terlalu menuntut memberikan tugas kepada siswa hanya saja diberikan latihan-latihan soal yang sesuai dengan materi berlangsung. Dan ada juga salah satu guru yang memberikan tugas kepada siswa dengan diberikan waktu selama 1 minggu untuk mengerjakan tugas tersebut. Setelah 1 minggu tugas selesai pihak orangtua datang ke sekolah untuk mengumpulkan tugas tersebut agar diberi nilai oleh guru.
Media yang digunakan pada saat pembelajaran daring itu mulai dari Zoom, Google Meet, sudah terlaksana dengan baik. Tetapi kadang kala terkendala dengan sinyal internet siswa. Dan juga menggunakan Google Form untuk mengerjakan tugas yang diberikan oleh guru dan untuk mengerjakannya tetap dibantu oleh orang tuanya dirumah sebagai pengawasan anak-anak pada saat pembelajaran daring berlangsung.

Minat belajar adalah salah satu faktor yang sangat penting untuk keberhasilan belajar yang dimiliki siswa, minat muncul dari dalam diri siswa itu sendiri. Faktor dari luar minat belajar yaitu bagaimana cara guru tersebut mengajar. Peran guru sangat penting untuk menumbuhkan minat belajar siswa salah satu dengan cara mengejar yang menyenangkan, memberikan motivasi yang membangun (Riamin, 2016).

Minat belajar juga mempunyai indikatorindikator didalamnya yaitu adanya perasaan tertarik dan juga senang untuk belajar, adanya partisipasi yang aktif, adanya kecenderungan untuk memperhatikan dan daya konsentrasi yang besar, memiliki perasaan positif dan kemauan belajar yang terus meningkat, adanya kenyamanan pada saat belajar, dan dimilikinya kapasitas dalam membuat keputusan sekaitan dengan proses belajar yang dijalaninya.

Cara untuk menumbuhkan minat belajar siswa yaitu memberikan video animasi yang menarik agar siswa itu tertarik pada pembelajaran yang sedang berlangsung. Dan dalam pembelajaran daring juga menyampaikan motivasi belajar dan semangat untuk belajar meskipun menyapa hanya secara virtual. 
240 Pengaruh Pembelajaran Daring terhadap Minat Belajar Siswa pada Masa COVID-19 - Ria Yunitasari, Umi Hanifah

DOI: https://doi.org/10.31004/edukatif.v2i3.142

Guru selalu memberikan motivasi kepada siswa pada saat pembelajaran daring berlangsung agar siswa itu tidak jenuh, tidak lemas, dan minat belajar siswa tetap ada. Dan juga memperhatikan siswa sebagaimana mestinya seperti di kelas. Jika siswa tidak mengetahui atau memahami tentang materi tersebut sebagai guru membantu siswa dalam mengalami kesulitan sehingga siswa paham dengan materi yang telah diberikan oleh guru.

Cara meningkatkan minat belajar kepada siswa sebagai berikut, minat belajar dapat ditingkatkan dengan tujuh langkah. Yang pertama, dengan mengartikulasikan tujuan pembelajaran atau menyusun tujuan pembelajaran yang sesuai dengan keadaan siswa. Yang kedua, dengan membuat relevansi antara materi pembelajaran dengan kehidupan akademik siswa dan yang mudah dipahami oleh siswa. Yang ketiga, dengan menunjukkan relevansi materi ajar dengan kehidupan profesional siswa, yang diketahui oleh siswa. Yang keempat, dengan menyoroti berbagai penerapan pengetahuan dan keterampilan di dunia nyata yang diketahui oleh siswa. Yang kelima, guru dapat menghubungkan pembelajaran dengan minat pribadi siswa. Yang keenam, memberikan kebebasan bagi siswa untuk membuat keputusan atau pilihan dan tidak memberatkan siswa. Terakhir, guru dapat menunjukkan gairah dan sikap antusias untuk meningkatkan minat belajar siswa agar siswa tidak mudah bosan pada waktu pembelajaran (Ricardo \& Meilani, 2017).

Siswa yang mempunyai minat terhadap suatu pelajaran akan mempelajarinya dengan sungguh-sungguh karena adanya daya tarik baginya, sehingga dapat didefinisikan bahwa minat belajar merupakan suatu keadaan yang menunjukkan kecenderungan perhatian atau tertarik terhadap suatu pelajaran tertentu.

Pembelajaran daring ini berpengaruh terhadap minat belajar siswa dikarenakan pembelajaran yang berbeda dari pembelajaran kelas. Minat belajar siswa bisa turun dikarenakan video yang diberikan kurang menarik. Jika pembelajaran dikelas kalau siswa minat belajarnya sudah turun dan tidak semangat lagi, biasanya guru memberikan permainan atau bernyanyi bersama. Dan bisa juga penerapan pembelajaran dikelas itu bisa diterapkan dalam pembelajaran daring meskipun tidak setiap hari agar siswa tidak mudah bosan pada proses pembelajaran daring berlangsung.

Guru juga mempunyai perbedaan dalam meningkatkan minat belajar siswa, bisa juga dengan cara selalu memotivasi siswanya agar tidak putus asa, tidak mudah bosan pada saat pembelajaran berlangsung.

Menurut salah satu responden, kelebihan dalam pembelajaran daring adalah masih bisa belajar meskipun di rumah yang biasanya disebut Pembelajaran Jarak Jauh (PJJ). Namun juga memiliki banyak kekurangn sepeti tidak bisa memantau siswa secara langsung, tidak bisa bertatap muka secara langsung, tidak bisa mengetahui karakter yang dimiliki oleh siswa, dan ada juga pemberian materi yang kurang efektif serta keterbatasan waktu pemberian materi.

Pada masa pandemi COVID-19 ini pembelajaran daring dilakukan dirumah dan siswa pada saat melaksanakan pembelajaran daring ini selalu didampingi oleh orang tua agar siswa tidak 
241 Pengaruh Pembelajaran Daring terhadap Minat Belajar Siswa pada Masa COVID-19 - Ria Yunitasari, Umi Hanifah

DOI: https://doi.org/10.31004/edukatif.v2i3.142

kebingungan pada saat diberikan materi oleh guru jika ada kesulitan agar orang tua bisa membantu anaknya. Tetapi tidak semua orang tua yang bisa mendampingi anaknya melakukan pembelajaran daring karena ada orang tua yang bekerja. Orang tua tidak mengalami kesulitan pada saat mendampingi anaknya melakukan proses pembelajaran daring dan juga memaklumi dengan adanya pembelajaran daring.

Menurut salah satu orang tua, pembelajaran daring ini sangat berpengaruh terhadap minat belajar siswa karena proses belajar yang berbeda. Ada kemungkian besar siswa menjadi malas atau tidak mau mengikuti pembelajaran daring yang sudah dijadwalkan oleh pihak sekolah, karena keinginan untuk bermain. Ada pula orangtua yang sesekali tidak memaksa anaknya untuk mengikuti pelajaran daring dari awal hingga akhir. Anak juga sering mengalami kebosanan dikarenakan hanya bertemu dengan teman-teman dan gurunya melalui media virtual atau biasanya menggunakan Zoom atau Google Meet tidak bertemu secara langsung.

Adanya bentuk penugasan via daring justru dianggap menjadi beban bagi sebagian siswa dan orang tua. Bagi siswa dan orang tua yang belum pernah mengenal gadget akan kebingungan dan akhirnya tidak menyelesaikan tugas yang diberikan oleh guru. Hal seperti ini biasanya terjadi pada siswa pada tingkat sekolah dasar. Istilah pembelajaran yang dijadikan solusi oleh pemerintah menjadi asing dikarenakan ketidaktersediaan fasilitas (Syarifudin, 2020,p.33).

Cara orang tua untuk menumbuhkan minat belajar anaknya dengan selalu memberikan semangat dan mendampingi pada saat proses pembelajaran daring berlangsung. Dan juga memberikan proses belajar dengan orang tua yang menyenangkan dengan melihat situasi dan kondisi. Orang tua juga selalu memberikan motivasi kepada anaknya agar tetap belajar dan mengikuti proses pembelajaran meskipun belajar dari rumah.

Cara orang tua untuk meningkatkan minat belajar anak salah satunya dengan cara memotivasi anak agar mau mengerjakan tugas sekolah yang diberikan oleh gurunya pada waktu pembelajaran daring sedang berlangsung dengan memberikan hadiah untuk prestasi yang telah dicapai agar anak lebih semangat untuk melakukan pembelajaran daring. Pemberian motivasi juga tidak harus memberikan hadiah kepada anak, bisa juga dengan pemberian semangat belajar secara lisan dengan perkataan yang positif dan membangun minat belajar anak itu sendiri. Selalu memberikan motivasi kepada anak bagaimana pentingnya belajar itu sendiri.

\section{KESIMPULAN}

Berdasarkan hasil penelitian yang sudah dilakukan, pembelajaran daring ini berpengaruh terhadap minat belajar siswa. Dikarenakan siswa menjadi mudah bosan ketika pembelajaran daring berlangsung.. Pembelajaran kurang menarik tidak seperti pembelajaran di kelas. Oleh karena itu, guru harus menciptakan pembelajaran daring yang menarik dan meningkatkan minat belajar siswa. Cara untuk menumbuhkan minat belajar pada siswa dengan memberikan motivasi-motivasi belajar kepada siswa dengan perkataan yang positif dan membangun siswa dalam kondisi 
242 Pengaruh Pembelajaran Daring terhadap Minat Belajar Siswa pada Masa COVID-19 - Ria Yunitasari, Umi Hanifah

DOI: https://doi.org/10.31004/edukatif.v2i3.142

belajar. Bisa juga dengan memperhatikan siswa pada saat pembelajaran daring berlangsung.

Saran bagi peneliti, guru dan orang tua selalu memberikan motivasi kepada siswa dan anaknya agar tidak cepat bosan dalam proses pembelajaran daring. Untuk guru bisa menciptakan pembelajaran yang menarik dan selalu memperhatikan siswa dalam proses pembelajaran daring yang berlangsung. Untuk orang tua juga memberikan kenyamanan dalam belajar, tidak selalu memaksa anak dalam belajar dan juga itu melihat situasi dan kondisi sang anak. Dan selalu memberikan perkataan positif dan yang membangun untuk semangat belajar anak, selalu mendampingi anak dalam proses pembelajaran dan membantu anak jika mendapatkan kesulitan dalam proses pembelajaran berlangsung.

\section{DAFTAR PUSTAKA}

Andriani, R., \& Rasto, R. (2019). Motivasi belajar sebagai determinan hasil belajar siswa. Jurnal Pendidikan Manajemen Perkantoran, 4(1),

80. https://doi.org/10.17509/jpm.v4i1.14958

Ashari, M. (2020). Proses Pembejalaran Daring di Tengah Antisipasi Penyebaran Virus Corona Dinilai Belum Maksimal. 20 Maret. https://www.pikiranrakyat.com/pendidikan/pr-01353818/prosespembejalaran-daring-di-tengah-antisipasipenyebaran-virus-corona-dinilai-belummaksimal

Aulia, S. (2020). Pembelajaran Daring Pada Masa Pandemi. 20 Juli. https://www.suara.com/yoursay/2020/07/20/1 75556/pembelajaran-daring-pada-masapandemi

Contesa, D. (2020). Hubungan Orang Tua dengan Minat Belajar Siswa pada Masa Covid-19. 21

Juni. https://mahasiswaindonesia.id/hubunganorang-tua-dengan-minat-belajar-siswa-padamasa-covid-19/

Dewi, W. A. F. (2020). Dampak COVID-19 terhadap Implementasi Pembelajaran Daring di Sekolah Dasar. Edukatif: Jurnal Ilmu Pendidikan, 2(1), 55-61. https://doi.org/10.31004/edukatif.v2i1.89

Fadli, R. (2020). Coronavirus. https://www.halodoc.com/kesehatan/coronavi rus

Harnani, S. (2020). EFEKTIVITAS PEMBELAJARAN DARING DI MASA PANDEMI COVID-19. 7 Juli. https://bdkjakarta.kemenag.go.id/berita/efekti vitas-pembelajaran-daring-di-masa-pandemicovid-19

Meidawati, dan S., \& Veteran Bangun Nusantara Sukoharjo, U. (2019). Pengaruh Daring Learning terhadap Hasil Belajar IPA Siswa Sekolah Dasar Abstrak. Seminar Nasional Sains \& Entrepreneurship, 1(1), 1-5. https://scholar.google.co.id/scholar?hl=id\&as _sdt $=0 \% 2 \mathrm{C} 5 \& \mathrm{q}=$ Pengaruh $+\mathrm{D}+\mathrm{a}+\mathrm{ri}+\mathrm{n}+\mathrm{g}+\mathrm{L}+$ $\mathrm{e}+\mathrm{a}+\mathrm{r}+\mathrm{n}+\mathrm{i}+\mathrm{n}+\mathrm{g}+$ terhadapHasilBelajarIPASis waSekolahDasar\&btnG=

Pakpahan, R., \& Fitriani, Y. (2020). JISAMAR (Journal of Information System, Applied, Management, Accounting and Researh). 4(2), 30-36.

Purwanto, A., Pramono, R., Asbari, M., Santoso, P. B., Wijayanti, L. M., Choi, C. H., \& Putri, R. S. (2020). Studi Eksploratif Dampak Pandemi COVID-19 Terhadap Proses Pembelajaran Online di Sekolah Dasar. EduPsyCouns: Journal of Education, Psychology and Counseling, 2(1), 1-12. https://ummaspul.ejournal.id/Edupsycouns/article/view/397

Riamin. (2016). Menumbuhkan Minat Belajar Siswa dalam Pembelajaran. 14 April. https://www.kompasiana.com/riamin/570ec6 323697738d1a3e38b6/menumbuhkan-minatbelajar-siswa-dalam-pembelajaran

Ricardo, R., \& Meilani, R. I. (2017). Impak Minat dan Motivasi Belajar Terhadap Hasil Belajar 
243 Pengaruh Pembelajaran Daring terhadap Minat Belajar Siswa pada Masa COVID-19 - Ria Yunitasari, Umi Hanifah

DOI: https://doi.org/10.31004/edukatif.v2i3.142

Siswa. Jurnal Pendidikan Manajemen

Perkantoran, 2(2), 79.

https://doi.org/10.17509/jpm.v2i2.8108

Sobron, A. ., Bayu, Rani, \& Meidawati. (2019).

Persepsi Siswa Dalam Studi Pengaruh Daring Learning Terhadap Minat Belajar IPA. SCAFFOLDING: Jurnal Pendidikan Islam Dan Multikulturalisme, 1(2), 30-38.

Sugiyono, P. D. (2015). METODE PENELITIAN PENDIDIKAN PENDEKATAN KUANTITATIF, KUALITATIF, DAN R\&D. ALFABETA, cv.

Syah, R. H. (2020). Dampak Covid-19 pada Pendidikan di Indonesia: Sekolah, Keterampilan, dan Proses Pembelajaran. SALAM: Jurnal Sosial Dan Budaya Syar-I, 7(5).

https://doi.org/10.15408/sjsbs.v7i5.15314

Syarifudin, A. S. (2020). Impelementasi Pembelajaran Daring Untuk Meningkatkan Mutu Pendidikan Sebagai Dampak Diterapkannya Social Distancing. Jurnal Pendidikan Bahasa Dan Sastra Indonesia Metalingua, 5(1), 31-34. https://doi.org/10.21107/metalingua.v5i1.707 2

Wahyono, P., \& Husamah, H. (2020). Jurnal pendidikan profesi guru. 1(1), 51-65.

Yanti, M. T., Kuntarto, E., \& Kurniawan, A. R. (2020). Pemanfaatan Portal Rumah Belajar Kemendikbud Sebagai Model Pembelajaran Daring Di Sekolah Dasar. Adi Widya Jurnal Pendidikan Dasar, 10(1), 61-68. https://doi.org/10.1017/CBO9781107415324. 004

Yunita, N. W. (2020). Penyebab, Asal Mula, dan Pencegahan Virus Corona di Indonesia. 28 Maret. https://m.detik.com/news/berita/d4956764/penyebab-asal-mula-danpencegahan-virus-corona-di-indonesia 